medRxiv preprint doi: https://doi.org/10.1101/2021.01.14.21249793; this version posted January 15, 2021. The copyright holder for this preprint (which was not certified by peer review) is the author/funder, who has granted medRxiv a license to display the preprint in perpetuity.

All rights reserved. No reuse allowed without permission.

Abstract Word Count: 299/300

Word Count: $3200 / 3200$

\title{
Real-Time Electronic Health Record Mortality Prediction During the COVID-19 Pandemic: A Prospective Cohort Study
}

Running Head: Real-Time Mortality Prediction During COVID-19

Peter D. Sottile, $\mathrm{MD}^{1}$, David Albers, $\mathrm{PhD}^{2}$, Peter E. DeWitt, $\mathrm{PhD}^{2}$, Seth Russell, MS ${ }^{3}$, J.N. Stroh, PhD ${ }^{4}$, David P. Kao, MD ${ }^{5}$, Bonnie Adrian, $\mathrm{PhD}^{6}$, Matthew E. Levine ${ }^{7}$, Ryan Mooney, $\mathrm{MS}^{8}$, Lenny Larchick, $\mathrm{BA}^{8}$, Jean S. Kutner, MD, MSPH ${ }^{9}$, Matthew K. Wynia, MD $^{10}$, Jeffrey J. Glasheen, $\mathrm{MD}^{11}$, Tellen D. Bennett, MD, $\mathrm{MS}^{2,12}$

${ }^{1}$ Division of Pulmonary Sciences and Critical Care Medicine, Department of Medicine, University of Colorado School of Medicine

${ }^{2}$ Section of Informatics and Data Science, Department of Pediatrics, University of Colorado School of Medicine

${ }^{3}$ Data Science to Patient Value Initiative, University of Colorado School of Medicine

${ }^{4}$ Department of Bioengineering, University of Colorado-Denver College of Engineering, Design, and Computing

${ }^{5}$ Divisions of Cardiology and Bioinformatics/Personalized Medicine, Department of Medicine, University of Colorado School of Medicine

${ }^{6}$ UCHealth Clinical Informatics and University of Colorado College of Nursing

${ }^{7}$ Department of Computational and Mathematical Sciences, California Institute of Technology

${ }^{8}$ UCHealth Hospital System

${ }^{9}$ Division of General Internal Medicine, Department of Medicine, University of Colorado School of Medicine, Chief Medical Officer, University of Colorado Hospital/UCHealth

${ }^{10}$ Center for Bioethics and Humanities, University of Colorado and Department of Medicine, University of Colorado School of Medicine

${ }^{11}$ Division of Hospital Medicine, Department of Medicine, University of Colorado School of Medicine and Chief Quality Officer, UCHealth

${ }^{12}$ Section of Critical Care Medicine, Department of Pediatrics, University of Colorado School of Medicine

Corresponding Author: Peter D Sottile, 12700 E. $19^{\text {th }}$ Ave, Research Complex 2, Mailstop C272, Aurora, $\mathrm{CO}, 80045$

All authors do not have a conflict of interests.

PS is supported by NIH K23 HL 145001, DA and ML by NIH R01 LM012734, DK by NIH K08 HL125725, TB by NIH UL1 TR002535 and UL1 TR002535-03S2. 
medRxiv preprint doi: https://doi.org/10.1101/2021.01.14.21249793; this version posted January 15, 2021. The copyright holder for this preprint

(which was not certified by peer review) is the author/funder, who has granted medRxiv a license to display the preprint in perpetuity.

All rights reserved. No reuse allowed without permission.

\author{
Abbreviations: \\ ALC - absolute lymphocyte count \\ APACHE II - Acute Physiology and Chronic Health Evaluation \\ ARDS - acute respiratory distress syndrome \\ AUROC - area under the receiver operating curve \\ $\mathrm{CCl}$ - Charlson Comorbidity Index \\ $\mathrm{Cl}$ - confidence interval \\ $\mathrm{CK}$ - creatinine kinase \\ $\mathrm{CSC}$ - crisis standard of care \\ EHR - electronic health record \\ HDC - Health Data Compass \\ ICU - intensive care unit \\ IT - information technology \\ $\mathrm{LDH}$ - lactate dehydrogenase \\ SAPS II - Simplified Acute Physiology Score \\ SOFA - Sequential Organ Failure Assessment \\ PSI - Pneumonia Severity Index
}


medRxiv preprint doi: https://doi.org/10.1101/2021.01.14.21249793; this version posted January 15, 2021. The copyright holder for this preprint

(which was not certified by peer review) is the author/funder, who has granted medRxiv a license to display the preprint in perpetuity.

All rights reserved. No reuse allowed without permission.

\section{Take Home Points}

Study Question: Can we improve upon the SOFA score for real-time mortality prediction during the COVID-19 pandemic by leveraging electronic health record (EHR) data?

Results: We rapidly developed and implemented a novel yet SOFA-anchored mortality model across 12 hospitals and conducted a prospective cohort study of 27,296 adult hospitalizations, 1,358 (5.0\%) of which were positive for SARS-CoV-2. The Charlson Comorbidity Index and SOFA scores predicted allcause mortality with AUROCs of 0.72 and 0.90 , respectively. Our novel score predicted mortality with AUROC 0.94.

Interpretation: A novel EHR-based mortality score can be rapidly implemented to better predict patient outcomes during an evolving pandemic. 
medRxiv preprint doi: https://doi.org/10.1101/2021.01.14.21249793; this version posted January 15, 2021. The copyright holder for this preprint (which was not certified by peer review) is the author/funder, who has granted medRxiv a license to display the preprint in perpetuity.

All rights reserved. No reuse allowed without permission.

\section{Abstract: (299/300 words)}

Background: The SARS-CoV-2 virus has infected millions of people, overwhelming critical care resources in some regions. Many plans for rationing critical care resources during crises are based on the Sequential Organ Failure Assessment (SOFA) score. The COVID-19 pandemic created an emergent need to develop and validate a novel electronic health record (EHR)-computable tool to predict mortality.

Research Questions: To rapidly develop, validate, and implement a novel real-time mortality score for the COVID-19 pandemic that improves upon SOFA.

Study Design and Methods: We conducted a prospective cohort study of a regional health system with 12 hospitals in Colorado between March 2020 and July 2020. All patients $>14$ years old hospitalized during the study period without a do not resuscitate order were included. Patients were stratified by the diagnosis of COVID-19. From this cohort, we developed and validated a model using stacked generalization to predict mortality using data widely available in the EHR by combining five previously validated scores and additional novel variables reported to be associated with COVID-19-specific mortality. We compared the area under the receiver operator curve (AUROC) for the new model to the SOFA score and the Charlson Comorbidity Index.

Results: We prospectively analyzed 27,296 encounters, of which $1,358(5.0 \%)$ were positive for SARSCoV-2, 4,494 (16.5\%) included intensive care unit (ICU)-level care, 1,480 (5.4\%) included invasive mechanical ventilation, and 717 (2.6\%) ended in death. The Charlson Comorbidity Index and SOFA scores predicted overall mortality with an AUROC of 0.72 and 0.90 , respectively. Our novel score predicted overall mortality with AUROC 0.94. In the subset of patients with COVID-19, we predicted mortality with AUROC 0.90, whereas SOFA had AUROC of 0.85 .

Interpretation: We developed and validated an accurate, in-hospital mortality prediction score in a live EHR for automatic and continuous calculation using a novel model, that improved upon SOFA.

Key Words: Crisis Triage, Mortality Prediction, COVID-19, Machine Learning 
medRxiv preprint doi: https://doi.org/10.1101/2021.01.14.21249793; this version posted January 15, 2021. The copyright holder for this preprint (which was not certified by peer review) is the author/funder, who has granted medRxiv a license to display the preprint in perpetuity.

All rights reserved. No reuse allowed without permission.

\section{Introduction:}

The SARS-CoV-2 virus has infected $>70$ million and killed $>1.5$ million people in the year since its origination (December 2019). ${ }^{1}$ The resulting pandemic has overwhelmed some regions' health care systems and critical care resources, forcing the medical community to confront the possibility of rationing resources. ${ }^{2,3}$ In the United States, critical care triage guidance in the setting of resource scarcity is produced at the state-level through Crisis Standards of Care (CSC) protocols. ${ }^{4,5}$ These protocols attempt the difficult task of ethically allocating scarce resources to individuals most likely to benefit, with the aim of saving the most lives. ${ }^{6-8}$ To accomplish this, CSC protocols use organ dysfunction scores and chronic comorbidity scores to assess patient survivability. Ideally, scoring would avoid systematic bias and be generalizable, accurate, flexible to circumstance, and computable within electronic health record (EHR) systems with data collected in real-time. ${ }^{9}$

At the foundation of most CSC protocols is the Sequential Organ Failure Assessment (SOFA) score. ${ }^{10,11}$ SOFA and other acuity scores, e.g., SAPSII and APACHE, are well-validated but have significant limitations. They were developed over 20 years ago before widespread electronic health records (EHRs), are rigid regarding context, and were designed to measure severity of illness and predict mortality based a few data points. ${ }^{12-17}$ Although SOFA predicts mortality from influenza pneumonia poorly, it was operationalized for use in patients with COVID-19. ${ }^{11,18,19}$ Optimizing the accuracy of mortality predictions is critical for medical triage because the decision to withhold or withdraw of life-sustaining therapies is heavily influenced by a single score in many states' CSC protocols. ${ }^{11}$

The COVID-19 pandemic created an emergent need for a novel, accurate, and context-sensitive EHRcomputable tool to predict mortality in hospitalized patients with and without COVID-19. Because developing a new score can take years, a predictive model must rely on well-validated scores, only adding new inputs to improve performance. Stacked generalization provides a solution. ${ }^{20} \mathrm{~A}$ stacked model is built upon one of or more baseline model (e.g. SOFA) and incorporates additional models only when they improve prediction. ${ }^{21}$

We rapidly developed and validated a novel mortality score for triage of all hospitalized patient during the COVID-19 pandemic by stacking SOFA, qSOFA, a widely used pneumonia mortality score, an acute respiratory distress syndrome (ARDS) mortality model, and a comorbidity score. ${ }^{12,22-25}$ We then integrated recently reported predictors that may reflect COVID-19 pathophysiology. To test the novel model, we conducted a prospective cohort study of acutely ill adults with and without COVID-19 disease.

\section{Study Design and Methods:}

We began by developing the novel mortality score using a multi-hospital retrospective cohort of 82,087 patient encounters (Figure 1 and Appendix A). We then conducted a prospective cohort study to validate the novel mortality score in patients with and without COVID-19. Our work was anchored by four goals. First, to use SOFA as a baseline and address its limitations through stacked generalization, adding other models with the potential to improve robustness and predictive performance. Second, to integrate and test potential COVID-19-specific predictors. Third, to rapidly deploy the new model in a live EHR across a 12-hospital system that serves more than 1.9 million patients. Fourth, to validate model performance prospectively. The Colorado Multiple Institutional Review Board approved this study (\#20-0995).

Workflow and Model Deployment 
Rapid development and implementation of a new score requires a full clinical and informatics pipeline including skilled data warehousing, data wrangling, machine learning, health system information technology (IT), and clinical and ethics personnel working in sync. ${ }^{26-28}$ All data flowed to the study team from UCHealth's Epic instance through Health Data Compass (HDC), the enterprise data warehouse for the University of Colorado Anschutz Medical Campus (Figure 1). ${ }^{29} \mathrm{HDC}$ is a multi-institutional data warehouse that links inpatient and outpatient electronic medical data, state-level all-payer claims data, and the Colorado Death Registry. The creation of data sets and models required identification of the correct data elements in both operational EHR and warehoused data tables to ensure accuracy and robustness. Rapid development, validation, and deployment of a novel model within the real-time EHR required close collaboration among three teams: 1) a data science team, 2) a clinical data warehouse team, and 3) a clinical informatics operations team (Appendix A).

This study design is consistent with recent learning health system studies. ${ }^{30}$ Because of the rapidly evolving pandemic, we built a data pipeline for the stacked mortality model to update as new data were captured from the EHR. We originally developed, validated and deployed the model using estimates from retrospective data, while simultaneously building technical capacity to transition to a model estimated on prospective data. The time from conception to deployment of the new model across the hospital system was one month.

\section{Prospective Cohort}

The prospective cohort included all encounters of patients $>14$ years old hospitalized at any of UCHealth's 12 acute care hospitals between March 15, 2020 (the date UCHealth halted elective procedures) through July 2020. Because CSC protocols apply to all hospitalized patients during a crisis, we included all inpatients regardless of level of care or COVID-19 status. We excluded encounters with a do not attempt resuscitation order placed within 12 hours of admission, patients who were still admitted, and encounters longer than 30 days.

\section{Model Methodology}

We developed a model using stacked generalization to predict mortality. ${ }^{20,31,32}$ A stacked regression model takes other component models as covariates and estimates weights in accordance with their predictive power. ${ }^{31}$ We chose ridge regularized logistic regression as the top-level model to limit overfitting and to address correlation between the component models. ${ }^{21}$ Stacking allows for robust, accurate, and interpretable evaluation of the underlying models. ${ }^{32}$ Moreover, the stacked model never performs worse than the most accurate component model (see Appendix A). ${ }^{33}$

The stacked regression takes six logistic regression mortality models as covariates. Four are validated organ dysfunction or pneumonia/ARDS mortality prediction tools, a fifth is a comorbidity score, and a sixth is novel and COVID-specific. These models include: (1) SOFA, (2) qSOFA, (3) the CURB-65 adult pneumonia mortality score, (4) a modified version of an ARDS mortality model, and (5) a Charlson Comorbidity Index (Appendix A). ${ }^{12,14,23-25}$ The ARDS mortality model was attenuated to include the subset of predictors reliably available in structured form in live EHRs. The sixth model includes variables hypothesized and reported to be associated with COVID-19-specific disease severity or mortality. This includes, for example, D-dimer, lactate dehydrogenase (LDH), absolute lymphocyte count (ALC), and creatinine kinase (CK, Appendix A). ${ }^{34-36}$ Variables such as gender, race, or disability status were not included in any models.

Real-time predicted mortality 
medRxiv preprint doi: https://doi.org/10.1101/2021.01.14.21249793; this version posted January 15, 2021. The copyright holder for this preprint (which was not certified by peer review) is the author/funder, who has granted medRxiv a license to display the preprint in perpetuity. All rights reserved. No reuse allowed without permission.

Probability of mortality varies over the hospital course (Appendix B) and can be estimated at any time during the hospitalization. Thus, to estimate and validate model parameters, we selected a single time point to make a prediction - when the SOFA score reached its maximum for the encounter.

Operationally, this framework allows for real-time mortality prediction under the assumption that the current measured state of the patient is the worst state the patient will experience. While this assumption will not be correct for all moments in time, it effectively underestimates the patient's overall mortality, thus reducing the chance for premature limitation of critical care resources if used for triage decisions.

\section{Model Training, Evaluation, and Validation:}

We divided the retrospective data $40 \%-40 \%-20 \%$ for estimating the baseline logistic regression models, estimating the stacked model, and evaluating the stacked model, respectively. We estimated the stacked models with regularized (ridge) logistic regression and used 3-fold cross-validation to select a regularization parameter. The final stacked model was evaluated using empirical-bootstrap-estimated confidence intervals ( $\mathrm{Cls}$ ) and a primary metric of area under the receiver operator curve (AUROC). We validated the stacked model using the prospective cohort and the AUROC.

We chose AUROC as the accuracy metric because the primary goal of the mortality score was to generate a ranked list of patients to inform the allocation of scare resources. The AUROC is an estimate of the probability of correctly ranking a case compared to a non-case. We also estimated other accuracy metrics including positive predictive value, sensitivity, specificity, accuracy, and F1-measure (see Appendix B, eFigure1).

To evaluate the impact of COVID-19 on mortality prediction, we retrained the model using the same training strategy but limited training data to patients with COVID-19. Specifically, we divided the cohort of patients with COVID-19 40\%-40\%-20\% for estimating the baseline logistic regression models, estimating the stacked model, and evaluating the stacked model, respectively.Ethical Considerations

This novel score was developed with the purpose of optimizing mortality prediction for crisis triage. Consequently, the score parameters needed to fall with the ethical framework developed for crisis triage. Briefly, in catastrophic circumstances the goal of a resource allocation processes should be to provide the most benefit to as many people as possible, and to do so in ways that sustain social cohesion and trust in the healthcare system. To maintain trust, recommendations for rationing of resources must be made prospectively, transparently and consistently across the institution and region, and by decision-makers independent of the care team. Moreover, any decision to ration resources must embrace a commitment to fairness and a proscription against rationing based on non-clinical factors such as race, gender, sexual orientation, disability, religious beliefs, citizenship status, or "VIP," socioeconomic,or insurance status. ${ }^{37-40}$ Consequently, factors such a race were excluded from score development, even if they had the potential to improve accuracy.

\section{Results:}

\section{Cohort Characteristics and Hospital Course:}

The prospective cohort included a total of 28,538 encounters between March $15^{\text {th }}, 2020$ and July 2020. Of these, 1,148 (4.0\%) were excluded because the patient remained in hospital at the time of data censoring: in-hospital survival could not be assessed. Additionally, we excluded 70 and 24 encounters respectivelydue to active DNR and encounter length $>30$ days. Of the remaining 27,296 encounters, $1,358(5.0 \%)$ were positive for SARS-CoV-2, 4,494 (16.5\%) included intensive care unit (ICU)-level care, $1,480(5.4 \%)$ included invasive mechanical ventilation, and 717 (2.6\%) died during the hospitalization. Of 
medRxiv preprint doi: https://doi.org/10.1101/2021.01.14.21249793; this version posted January 15, 2021. The copyright holder for this preprint (which was not certified by peer review) is the author/funder, who has granted medRxiv a license to display the preprint in perpetuity.

All rights reserved. No reuse allowed without permission.

the 717 patients who received mechanical ventilation, 408 (27.6\%) died. Additional demographics are in Table 1, eTable 1, and eTable 2.

Of the 1,358 encounters positive for COVID-19, 407 (30.0\%) received ICU-level care, 239 (17.6\%) were intubated, and 166 (12.2\%) patients died. Of the 239 patients requiring mechanical ventilation, 83 (34.7\%) died.

Compared to patients without COVID-19, patients with COVID-19 were more likely to be male ( $55.6 \%$ vs $42.0 \%, p<0.001$ ), be Hispanic ( $44.4 \%$ vs $14.6 \%, p<0.001$ ), receive ICU-level care $(30.0 \%$ vs $15.8 \%$, $\mathrm{p}<0.001)$, be intubated ( $17.6 \%$ vs $4.8 \%, p<0.001)$, have a longer duration of mechanical ventilation ( 8.7 days vs 3.0 days, $p<0.001$ ), a longer hospital length of stay ( 7.6 days vs 4.3 days, $p<0.001$ ), and not survive (12.2\% vs $2.1 \%, p<0.001)$. Patients with COVID-19 had higher SOFA and CURB-65 scores and LDH, ferritin, and D-dimer levels than patients without COVID-19 (all $p<0.05$, Table 2). Mean troponin levels were lower in patients with COVID-19 compared to patients without COVID-19 ( $p=0.002$, Table 2). However, absolute lymphocyte count and creatinine kinase levels were not dissimilar between groups (all $p>0.05$, Table 2).

Point-Wise Mortality Estimates:

When validating mortality models in the prospective cohort, the individual component models predicted point-wise mortality (estimates of mortality risk ranging from 1-99\%) with AUROCs ranging from 0.72 (Charlson Comorbidity Index) to 0.90 (SOFA) (Table 3). The stacked model predicted point-wise mortality better than any individual model: AUROC 0.94 (Figure 2). Most prospective encounters (95.7\%) had predicted point-wise mortalities less than $10 \%$. Within this group, observed mortality was only $1.0 \%$, suggesting that the stacked model accurately identifies patients with low mortality (eTable 3).

In patients with COVID-19, the AUROC for SOFA, CURB-65, the Charlson Comorbidity Index, and novel variables was $0.85,0.90,0.75$, and 0.91 respectively. In this subset of patients, the stacked model predicted mortality with an AUROC of 0.90 . In both analyses, the stacked model predicted mortality with narrowest 95\% confidence intervals at the extremes of predicted mortality (eFigure 2). Even at moderate predicted mortalities, 95\% confidence intervals were generally narrower than ten percentage points. Additional results including precision, recall, and time-integrated estimates of mortality are reported in Appendix B, eFigure 1.

When trained with retrospective data and evaluated on patients with COVID-19, the novel model outperformed the stacked model (AUROCs of 0.91 and 0.90 , respectively). However, re-training the stacked model only on patients with COVID-19 improved its COVID-19-specific AUROC to 0.95 (Appendix B). The stacked model outperformed all other models for patients with COVID-19. This highlights the importance of flexible modeling constructs and suggests that patients with COVID-19 have predictors of mortality that differ from average patients.

\section{Discussion:}

We developed a new, accurate mortality prediction score that is adaptable to different diseases and settings. Improving upon SOFA and the Charlson Comorbidity Index to predict mortality, our score allows more accurate and granular ranking of patients likely to benefit from intensive care. We rapidly deployed the novel score in our EHR during the COVID-19 pandemic for potential real-time use in making triage decisions. We demonstrated that reliability was maintained in a prospective cohort of patients with and without COVID-19. Fortunately, we have not needed to use these scores for triage, but our development process forges a new path for leveraging EHRs, clinical expertise, and machine learning to provide real time, situation-critical clinical decision support. 
medRxiv preprint doi: https://doi.org/10.1101/2021.01.14.21249793; this version posted January 15, 2021. The copyright holder for this preprint (which was not certified by peer review) is the author/funder, who has granted medRxiv a license to display the preprint in perpetuity. All rights reserved. No reuse allowed without permission.

This paper adds significantly to the literature regarding CSC and ethically allocating scarce medical resources. Like ours, most other scoring systems are based on the SOFA score, which was developed 20 years ago with simplicity and not triage in mind. SOFA predicted influenza H1N1 mortality poorly. ${ }^{18,19}$ Others have attempted to build novel scores that are simple and accurate. ${ }^{6,7}$ Our work builds on recent reports demonstrating in patients with COVID-19 that SOFA, CURB-65, PSI, APACHE II, and novel, COVIDspecific COVID-GRAM scores predict mortality well: AUROC $0.87,0.84-0.85,0.87,0.96$, and $0.78-0.88$ respectively. ${ }^{41-44}$ Although APACHE II out-performs other scores, it includes data that is not easily extracted from an EHR in real-time. By stacking multiple models and using data extracted in real-time from the EHR, we demonstrate similar AUROC (0.94) in a large prospective cohort of patients on whom a CSC-based triage plan would operate: those with and without COVID-19. Finally, CSC protocols have collapsed SOFA scores to rank patients in just a few categories, reflecting the difficulty of knowing when SOFA scores are sufficiently different to make a meaningful difference for triage. Our approach generates $1-99 \%$ risk of mortality and the ability to statistically differentiate between patients (or determine statistical ties) by calculating $95 \% \mathrm{Cl}$ for each score.

Our stacked model's ability to predict mortality is tailored to our patient population in Colorado. This is important given the varied experiences with COVID-19. Our in-hospital (12\% versus $21 \%$ ) and ventilator mortality rates ( $35 \%$ versus $88 \%$ ) were substantially lower than a New York cohort. ${ }^{45}$ Our mortality rates approach those expected for moderate-severe ARDS. ${ }^{46,47}$ There are potentially many explanations for these differences, including younger age, difference in comorbidities, differences in therapeutic interventions, and learning from the experience of earlier effected areas. Moreover, the utilization of ICU level of care and mechanical ventilation varies widely across the world: in New York, $14.2 \%$ of patients were treated in an ICU and $12.2 \%$ of patient received mechanical ventilation. In contrast, in a cohort of patients in China, $50.6 \%$ of patients were admitted to an ICU and $42.2 \%$ received mechanical ventilation. ${ }^{35,36,41}$ Such differences may affect the predictive characteristics of a mortality score. Moreover, we found that patients with COVID-19 have unique characteristics and may benefit from specific mortality prediction models. Thus, utilizing EHR data streams allows for flexibility to add additional components and retrain the stacked model as new knowledge and clinical experience accumulates. Importantly for generalization, the model can be tuned in real-time to other local patient populations and disease characteristics.

Several aspects of the informatics infrastructure and workflow are important. First, such a rapid development process would have been impossible without a robust data warehouse staffed by experts with deep knowledge of EHR data and common clinical data models. The availability of high-quality data is known to be among the largest challenges in clinical applications of machine learning. ${ }^{48}$ Second, our data science team was in place and had substantial shared experience with data from the health system. It would be extremely challenging to either rapidly hire or outsource the necessary expertise during a pandemic. Third, our data science team already had access to highly capable cloud-based and onpremises HIPAA-compliant computational environments. Establishing the processes and controls for such an environment takes time and expert human resources; our campus had already made those investments. Fourth, our multidisciplinary team included leadership, a variety of potential end-users, and experts from ethics, clinical informatics, machine learning, and clinical care. ${ }^{26}$ This diversity critically grounded the project in ethical principles and pragmatic clinical realties and allowed us to quickly iterate to a practical, implementable, and interpretable model. Because of urgent operational needs, we also had full institutional and regulatory support. Finally, we evaluated the model prospectively, an important gold-standard not often met by new machine learning-based informatic tools. ${ }^{26}$ Of note, there are many reports in the literature describing development of predictive models using EHR data, 
medRxiv preprint doi: https://doi.org/10.1101/2021.01.14.21249793; this version posted January 15, 2021. The copyright holder for this preprint (which was not certified by peer review) is the author/funder, who has granted medRxiv a license to display the preprint in perpetuity.

All rights reserved. No reuse allowed without permission.

but very few reports of the implementation of those models in a live EHR for clinical use. In this case, the total elapsed time from including data extraction, model construction, implementation, and deployment within the EHR across the 12 UCHealth hospitals was 1 month, illustrating the potential capacity for novel predictive model development. Now that we have demonstrated a workflow to rapidly develop new informatics tools in our health system, we anticipate that many other tools will follow.

This manuscript has several limitations. First, all scores are calculated from EHR data. While this allows for real-time score calculation, it introduces the possibility of artifactual data skewing mortality prediction. This was partially addressed by placing acceptable ranges on physiologic variables (see Appendix A). Second, missing data or data collected at different time intervals is inherent in the analysis of EHR data. To overcome this, we developed a system of imputation and last known value carry forward (see Appendix A). Such assumptions may introduce systematic and unmeasured bias but are unavoidable operationally. Third, more sophisticated machine learning techniques-e.g., Gaussian process regressions-may allow for more accurate mortality predictions. ${ }^{49}$ However, we chose methods that were robustly estimable and would allow for transparent interpretation of underlying model contributions to the overall score. Fourth, in-hospital mortality may not be the optimal metric to make triage decisions. One-year mortality may be a better metric but, given the desire to validate a mortality predictor quickly, longer-term outcomes were not available. Fifth, our data and patient population are specific to Colorado and results may differ geographically. Finally, some clinical indicators of illness severity were not included in the models, e.g. prone positioning, continuous renal replacement therapy, and radiographic results. These data may improve mortality prediction but are difficult to routinely and reliably auto-extract from the EHR.

\section{Conclusion:}

We developed a novel and accurate in-hospital mortality score that was deployed in a live EHR and automatically and continuously calculated for real-time evaluation of patient mortality. The score can be tuned to a local population and updated to reflect emerging knowledge regarding COVID-19. Moreover, this score adheres to the ethical principles necessary for triaging. ${ }^{37-40}$ Further research to test multicenter score performance, refine mortality prediction over longer periods of time, and investigate the optimal methods to use such a score in a CSC protocol is needed. 
medRxiv preprint doi: https://doi.org/10.1101/2021.01.14.21249793; this version posted January 15, 2021. The copyright holder for this preprint (which was not certified by peer review) is the author/funder, who has granted medRxiv a license to display the preprint in perpetuity. All rights reserved. No reuse allowed without permission.

\section{Acknowledgements}

Guarantor: Tellen D. Bennett

Author Contributions:

TDB had full access to all of the data in the study and takes responsibility for the integrity of the data and the accuracy of the data analysis. PDS, DA, PED, SR, JS, TDB contributed substantially to the study design, data acquisition, data analysis and interpretation, and the writing of the manuscript. DPK, BA, $\mathrm{RM}$, and LL contributed substantially to data acquisition, verifying data integrity, and the writing of the manuscript. MEK contributed substantially to study design and the writing of the manuscript. JSK, MKW, JJG contributed substantially to the study design, data acquisition, and the writing of the manuscript.

Funding Sources: PS is supported by NIH K23 HL 145001, DA and ML by NIH R01 LM012734, DK by NIH K08 HL125725, TB by NIH UL1 TR002535 and NIH UL1 TR002535 - $03 S 2$.

Conflicts of Interest: None

Other Contributions: We would like to acknowledge Sarah Davis, Michelle Edelmann, and Michael Kahn at Health Data Compass. 
medRxiv preprint doi: https://doi.org/10.1101/2021.01.14.21249793; this version posted January 15, 2021. The copyright holder for this preprint (which was not certified by peer review) is the author/funder, who has granted medRxiv a license to display the preprint in perpetuity.

All rights reserved. No reuse allowed without permission.

\section{References:}

1. Dong E, Du H, Gardner L. An interactive web-based dashboard to track COVID-19 in real time. Lancet Infect Dis. 2020;3099(20):19-20. doi:10.1016/S1473-3099(20)30120-1

2. Modeling COVID-19 scenarios for the United States. Nat Med. October 2020. doi:10.1038/s41591-020-1132-9

3. Livingston E, Bucher K. Coronavirus Disease 2019 (COVID-19) in Italy. JAMA. 2020;2019:2020. doi:10.1001/jama.2020.4344

4. Subject Matter Experts Advisory Panel for the Governors Expert Emergency Epidemic Response Committee on Crisis Standards of Care Guidelines for Hospitals for the COVID-19 Pandemic. 2nd ed.; 2020. https://www.colorado.gov/pacific/cdphe/colorado-crisis-standards-care. Accessed May 15, 2020.

5. Minnesota Crisis Standards of Care.; 2020. https://www.health.state.mn.us/communities/ep/surge/crisis/index.html.

6. Talmor D, Jones AE, Rubinson L, Howell MD, Shapiro NI. Simple triage scoring system predicting death and the need for critical care resources for use during epidemics. Crit Care Med. 2007;35(5):1251-1256. doi:10.1097/01.CCM.0000262385.95721.CC

7. Adeniji KA, Cusack R. The Simple Triage Scoring System (STSS) successfully predicts mortality and critical care resource utilization in H1N1 pandemic flu: A retrospective analysis. Crit Care. 2011;15(1):R39. doi:10.1186/cc10001

8. Grissom CK, Brown SM, Kuttler KG, et al. A Modified Sequential Organ Failure Assessment Score for Critical Care Triage. Disaster Med Public Health Prep. 2010;4(4):277-284. doi:10.1001/dmp.2010.40

9. Wynia MK, Sottile PD. Ethical Triage Demands a Better Triage Survivability Score. Am J Bioeth. 2020;20(7). doi:10.1080/15265161.2020.1779412

10. Matheny Antommaria AH, Gibb TS, McGuire AL, et al. Ventilator Triage Policies During the COVID-19 Pandemic at U.S. Hospitals Associated With Members of the Association of Bioethics Program Directors. Ann Intern Med. April 2020:M20-1738. doi:10.7326/M20-1738

11. Piscitello GM, Kapania EM, Miller WD, Rojas JC, Siegler M, Parker WF. Variation in Ventilator Allocation Guidelines by US State During the Coronavirus Disease 2019 Pandemic. JAMA Netw Open. 2020;3(6). doi:10.1001/jamanetworkopen.2020.12606

12. Vincent JL, Moreno R, Takala J, et al. The SOFA (Sepsis-related Organ Failure Assessment) score to describe organ dysfunction/failure. On behalf of the Working Group on Sepsis-Related Problems of the European Society of Intensive Care Medicine. Intensive Care Med. 1996;22(7):707-710. doi:10.1007/bf01709751

13. Vincent JL, de Mendonça A, Cantraine F, et al. Use of the SOFA score to assess the incidence of organ dysfunction/failure in intensive care units: results of a multicenter, prospective study. Working group on "sepsis-related problems" of the European Society of Intensive Care Medicine. Crit Care Med. 1998;26(11):1793-1800. doi:10.1097/00003246-199811000-00016

14. Asai $\mathrm{N}$, Watanabe $\mathrm{H}$, Shiota $\mathrm{A}$, et al. Efficacy and accuracy of qSOFA and SOFA scores as 
medRxiv preprint doi: https://doi.org/10.1101/2021.01.14.21249793; this version posted January 15, 2021. The copyright holder for this preprint (which was not certified by peer review) is the author/funder, who has granted medRxiv a license to display the preprint in perpetuity.

All rights reserved. No reuse allowed without permission.

prognostic tools for community-acquired and healthcare-associated pneumonia. Int J Infect Dis. 2019;84:89-96. doi:10.1016/j.ijid.2019.04.020

15. Le Gall JR, Lemeshow S, Saulnier F. A new Simplified Acute Physiology Score (SAPS II) based on a European/North American multicenter study. JAMA. 1993;270(24):2957-2963.

doi:10.1001/jama.270.24.2957

16. Moreno R, Vincent JL, Matos $\mathrm{R}$, et al. The use of maximum SOFA score to quantify organ dysfunction/failure in intensive care. Results of a prospective, multicentre study. Intensive Care Med. 1999;25(7):686-696. doi:10.1007/s001340050931

17. Ferreira FL. Serial Evaluation of the SOFA Score to Predict Outcome in Critically III Patients. JAMA. 2001;286(14):1754. doi:10.1001/jama.286.14.1754

18. Guest T, Tantam G, Donlin N, Tantam K, McMillan H, Tillyard A. An observational cohort study of triage for critical care provision during pandemic influenza: "Clipboard physicians" or "evidenced based medicine"? Anaesthesia. 2009;64(11):1199-1206. doi:10.1111/j.1365-2044.2009.06084.x

19. Khan Z, Hulme J, Sherwood N. An assessment of the validity of SOFA score based triage in H1N1 critically ill patients during an influenza pandemic. Anaesthesia. 2009;64(12):1283-1288.

doi:10.1111/j.1365-2044.2009.06135.x

20. Wolpert DH. Stacked generalization. Neural Networks. 1992;5(2):241-259. doi:10.1016/S08936080(05)80023-1

21. Hastie T, Tibshirani R, Friedman J. The Elements of Statistical Learning. New York, NY: Springer New York; 2009. doi:10.1007/978-0-387-84858-7

22. Song J-U, Sin CK, Park HK, Shim SR, Lee J. Performance of the quick Sequential (sepsis-related) Organ Failure Assessment score as a prognostic tool in infected patients outside the intensive care unit: a systematic review and meta-analysis. Crit Care. 2018;22(1):28. doi:10.1186/s13054018-1952-x

23. Cooke CR, Kahn JM, Caldwell E, et al. Predictors of hospital mortality in a population-based cohort of patients with acute lung injury*. Crit Care Med. 2008;36(5):1412-1420.

doi:10.1097/CCM.0b013e318170a375

24. Quan H, Li B, Couris CM, et al. Updating and Validating the Charlson Comorbidity Index and Score for Risk Adjustment in Hospital Discharge Abstracts Using Data From 6 Countries. Am J Epidemiol. 2011;173(6):676-682. doi:10.1093/aje/kwq433

25. Charlson ME, Pompei P, Ales KL, MacKenzie CR. A new method of classifying prognostic comorbidity in longitudinal studies: Development and validation. J Chronic Dis. 1987;40(5):373383. doi:10.1016/0021-9681(87)90171-8

26. Wiens J, Saria S, Sendak M, et al. Do no harm: a roadmap for responsible machine learning for health care. Nat Med. 2019;25(9):1337-1340. doi:10.1038/s41591-019-0548-6

27. Rossetti SC, Knaplund C, Albers D, et al. Leveraging Clinical Expertise as a Feature - not an Outcome - of Predictive Models: Evaluation of an Early Warning System Use Case. AMIA . Annu Symp proceedings AMIA Symp. 2019;2019:323-332.

http://www.ncbi.nlm.nih.gov/pubmed/32308825. 
medRxiv preprint doi: https://doi.org/10.1101/2021.01.14.21249793; this version posted January 15, 2021. The copyright holder for this preprint (which was not certified by peer review) is the author/funder, who has granted medRxiv a license to display the preprint in perpetuity.

All rights reserved. No reuse allowed without permission.

28. Collins SA, Cato K, Albers D, et al. Relationship between nursing documentation and patients' mortality. Am J Crit Care. 2013;22(4):306-313. doi:10.4037/ajcc2013426

29. HealthData Compass. healthdatacompass.org. Accessed May 15, 2020.

30. Semler MW, Self WH, Wanderer JP, et al. Balanced Crystalloids versus Saline in Critically III Adults. N Engl J Med. 2018;378(9):829-839. doi:10.1056/NEJMoa1711584

31. Sill J, Takacs G, Mackey L, Lin D. Feature-Weighted Linear Stacking. November 2009. http://arxiv.org/abs/0911.0460.

32. Clark B. Comparing bayes model averaging and stacking when model approximation error cannot be ignored. JMLR. 2003:683-712. doi:10.1162/153244304773936090

33. Breiman L. Stacked regressions. Mach Learn. 1996;24(1):49-64. doi:10.1007/BF00117832

34. Wu C, Chen X, Cai Y, et al. Risk Factors Associated With Acute Respiratory Distress Syndrome and Death in Patients With Coronavirus Disease 2019 Pneumonia in Wuhan, China. JAMA Intern Med. March 2020:1-10. doi:10.1001/jamainternmed.2020.0994

35. Zhou F, Yu T, Du R, et al. Clinical course and risk factors for mortality of adult inpatients with COVID-19 in Wuhan, China: a retrospective cohort study. Lancet (London, England). 2020;395(10229):1054-1062. doi:10.1016/S0140-6736(20)30566-3

36. Goyal P, Choi JJ, Pinheiro LC, et al. Clinical Characteristics of Covid-19 in New York City. N Engl J Med. April 2020:NEJMc2010419. doi:10.1056/NEJMc2010419

37. Persad G, Wertheimer A, Emanuel EJ. Principles for allocation of scarce medical interventions. Lancet. 2009;373(9661). doi:10.1016/S0140-6736(09)60137-9

38. Truog RD, Mitchell C, Daley GQ. The Toughest Triage - Allocating Ventilators in a Pandemic. $N$ Engl J Med. 2020;382(21). doi:10.1056/NEJMp2005689

39. Maves RC, Downar J, Dichter JR, et al. Triage of Scarce Critical Care Resources in \{COVID\}-19 An Implementation Guide for Regional Allocation: An Expert Panel Report of the Task Force for Mass Critical Care and the American College of Chest Physicians. 0(0). doi:10.1016/j.chest.2020.03.063

40. White DB. Who Should Receive Life Support During a Public Health Emergency? Using Ethical Principles to Improve Allocation Decisions. Ann Intern Med. 2009;150(2). doi:10.7326/0003-4819150-2-200901200-00011

41. Zou X, Li S, Fang M, et al. Acute Physiology and Chronic Health Evaluation II Score as a Predictor of Hospital Mortality in Patients of Coronavirus Disease 2019. Crit Care Med. May 2020:1. doi:10.1097/CCM.0000000000004411

42. Shi Y, Pandita A, Hardesty A, et al. Validation of pneumonia prognostic scores in a statewide cohort of hospitalized patients with COVID-19. Int J Clin Pract. December 2020.

doi:10.1111/ijcp.13926

43. García Clemente MM, Herrero Huertas J, Fernández Fernández A, et al. Assessment of risk scores in Covid-19. Int J Clin Pract. November 2020. doi:10.1111/ijcp.13705

44. Liang W, Liang H, Ou L, et al. Development and Validation of a Clinical Risk Score to Predict the Occurrence of Critical Illness in Hospitalized Patients With COVID-19. JAMA Intern Med. 
medRxiv preprint doi: https://doi.org/10.1101/2021.01.14.21249793; this version posted January 15, 2021. The copyright holder for this preprint

(which was not certified by peer review) is the author/funder, who has granted medRxiv a license to display the preprint in perpetuity.

All rights reserved. No reuse allowed without permission.

2020;180(8). doi:10.1001/jamainternmed.2020.2033

45. Richardson S, Hirsch JS, Narasimhan M, et al. Presenting Characteristics, Comorbidities, and Outcomes Among 5700 Patients Hospitalized With COVID-19 in the New York City Area. JAMA. April 2020. doi:10.1001/jama.2020.6775

46. Bellani G, Laffey JG, Pham T, et al. Epidemiology, Patterns of Care, and Mortality for Patients With Acute Respiratory Distress Syndrome in Intensive Care Units in 50 Countries. JAMA.

2016;315(8):788. doi:10.1001/jama.2016.0291

47. Ziehr DR, Alladina J, Petri CR, et al. Respiratory Pathophysiology of Mechanically Ventilated Patients with COVID-19: A Cohort Study. Am J Respir Crit Care Med. April 2020:rccm.2020041163LE. doi:10.1164/rccm.202004-1163LE

48. Rajkomar A, Dean J, Kohane I. Machine Learning in Medicine. N Engl J Med. 2019;380(14):13471358. doi:10.1056/NEJMra1814259

49. Rasmussen CE, Williams CK. Gaussian Processes in Machine Learning. Boston: The MIT Press; 2006. 
medRxiv preprint doi: https://doi.org/10.1101/2021.01.14.21249793; this version posted January 15, 2021. The copyright holder for this preprint (which was not certified by peer review) is the author/funder, who has granted medRxiv a license to display the preprint in perpetuity.

All rights reserved. No reuse allowed without permission.

Table 1: Prospective Cohort Characteristics and Hospital Course

\begin{tabular}{|c|c|c|c|c|}
\hline & $\begin{array}{l}\text { All Encounters } \\
(\mathrm{N}=27,296)\end{array}$ & $\begin{array}{l}\text { COVID-19 Negative } \\
(\mathrm{N}=25,938)\end{array}$ & $\begin{array}{l}\text { CovID-19 Positive } \\
(\mathrm{N}=1,358)\end{array}$ & P-value \\
\hline Age (SD) & $54.3(20.4)$ & $54.2(20.5)$ & $56.8(18.4)$ & $P<0.001$ \\
\hline Female & $15,660(57.4 \%)$ & $15,057(58.0 \%)$ & $603(44.4 \%)$ & $P<0.001$ \\
\hline Race & & & & $P<0.001$ \\
\hline White or Caucasian & $20,430(74.8 \%)$ & $19,848(76.5 \%)$ & $582(42.9 \%)$ & \\
\hline $\begin{array}{l}\text { Black or African } \\
\text { American }\end{array}$ & $1,964(7.2 \%)$ & $1,790(6.9 \%)$ & $174(12.8 \%)$ & \\
\hline Other & $4,481(16.4 \%)$ & 3,901 (15.0\%) & $580(42.7 \%)$ & \\
\hline Unknown & $421(1.5 \%)$ & $399(1.5 \%)$ & $22(1.6 \%)$ & \\
\hline Ethnicity & & & & $P<0.001$ \\
\hline Non-Hispanic & $22,496(82.4 \%)$ & $21,755(83.9 \%)$ & 741 (54.6\%) & \\
\hline Hispanic & 4,398 (16.1\%) & 3,795 (14.6\%) & $603(44.4 \%)$ & \\
\hline Unknown & $402(1.5 \%)$ & $388(1.5 \%)$ & $14(1.0 \%)$ & \\
\hline Supplemental 02 & $16,052(58.8 \%)$ & $14,859(57.3 \%)$ & $1,193(87.8 \%)$ & $P<0.001$ \\
\hline $\begin{array}{l}\text { High Flow Nasal } \\
\text { Cannula }\end{array}$ & $1,398(5.1 \%)$ & 1,057 (4.1\%) & 341 (25.1\%) & $P<0.001$ \\
\hline $\begin{array}{l}\text { Non-Invasive } \\
\text { Ventilation }\end{array}$ & $1,482(5.4 \%)$ & $1,382(5.3 \%)$ & $100(7.4 \%)$ & $P<0.001$ \\
\hline $\begin{array}{l}\text { Median Hospital Days } \\
\text { (IQR) }\end{array}$ & $3.0(2.0,5.2)$ & $3.0(1.9,5.0)$ & $5.5(3.0,9.6)$ & $P<0.001$ \\
\hline Overall Mortality & 717 (2.6\%) & $551(2.1 \%)$ & $166(12.2 \%)$ & $P<0.001$ \\
\hline $\begin{array}{l}\text { All Mechanical } \\
\text { Ventilation }\end{array}$ & $1,480(5.4 \%)$ & $1,241(4.8 \%)$ & $239(17.6 \%)$ & $P<0.001$ \\
\hline $\begin{array}{l}\text { Median Hospital } \\
\text { Days (IQR) }\end{array}$ & $8.4(4.6,15.1)$ & $7.7(4.1,13.3)$ & $15.2(8.2,21.0)$ & $P<0.001$ \\
\hline $\begin{array}{l}\text { Median ICU Days } \\
\text { (IQR) }\end{array}$ & $3.6(1.6,7.8)$ & $2.9(1.4,6.2)$ & $9.1(5.3,15.0)$ & $P<0.001$ \\
\hline $\begin{array}{l}\text { Median Ventilator } \\
\text { Days (IQR) }\end{array}$ & $1.8(0.7,5.7)$ & $1.4(0.6,3.9)$ & $7.5(4.5,12.6)$ & $P<0.001$ \\
\hline Mortality & $408(27.6 \%)$ & $325(26.2 \%)$ & $83(34.7 \%)$ & $P=0.009$ \\
\hline
\end{tabular}

Reported $p$-values are to assess differences between COVID-19 Negative and COVID-19 Positive encounters. 
medRxiv preprint doi: https://doi.org/10.1101/2021.01.14.21249793; this version posted January 15, 2021. The copyright holder for this preprint (which was not certified by peer review) is the author/funder, who has granted medRxiv a license to display the preprint in perpetuity.

All rights reserved. No reuse allowed without permission.

Table 2: Mortality Model Inputs

\begin{tabular}{|c|c|c|c|c|}
\hline & $\begin{array}{l}\text { All Encounters } \\
(\mathrm{N}=\mathbf{2 7 , 2 9 6 )}\end{array}$ & $\begin{array}{l}\text { CovID-19 Negative } \\
\qquad(\mathrm{N}=\mathbf{2 5}, 938)\end{array}$ & $\begin{array}{l}\text { CovID-19 Positive } \\
\qquad(N=1,358)\end{array}$ & P-value \\
\hline \multicolumn{5}{|l|}{ Scores } \\
\hline Median qSOFA (IQR) & $0.0(0.0,1.0)$ & $0.0(0.0,1.0)$ & $0.1(0.0,1.0)$ & $P<0.001$ \\
\hline Median SOFA (IQR) & $2.0(2.0,4.0)$ & $2.0(2.0,3.0)$ & $3.0(2.0,5.0)$ & $P<0.001$ \\
\hline Median CURB-65 (IQR) & $1.0(0.1,2.0)$ & $1.0(0.1,2.0)$ & $1.0(0.0,2.0)$ & $P=0.44$ \\
\hline $\begin{array}{l}\text { Charlson Comorbidity } \\
\text { Index (IQR) }\end{array}$ & $1.0(0.0,3.0)$ & $1.0(0.0,3.0)$ & $1.0(0.0,2.0)$ & $P=0.38$ \\
\hline \multicolumn{5}{|l|}{ ARDS Mortality Model } \\
\hline Transfusion FFP & $59(0.2 \%)$ & $59(0.2 \%)$ & $0(0.0 \%)$ & $P=0.14$ \\
\hline Transfusion PRBC & $396(1.5 \%)$ & $392(1.5 \%)$ & $4(0.3 \%)$ & $P<0.001$ \\
\hline $\mathrm{GCS} \leq 8$ & $264(1.0 \%)$ & $246(0.9 \%)$ & $18(1.3 \%)$ & $P=0.21$ \\
\hline Lactate $>2$ & $2,676(9.8 \%)$ & $2,503(9.6 \%)$ & $173(12.7 \%)$ & $P<0.001$ \\
\hline Creatinine $\geq 2$ & $2,486(9.1 \%)$ & $2,323(9.0 \%)$ & $163(12.0 \%)$ & $P<0.001$ \\
\hline Mean Bilirubin (SD) & $0.7 \pm 2.0$ & $0.7 \pm 2.0$ & $0.6 \pm 0.8$ & $P=0.003$ \\
\hline Mean Arterial pH (SD) & $7.4 \pm 0.0$ & $7.4 \pm 0.0$ & $7.4 \pm 0.1$ & $P=0.001$ \\
\hline Mean PF (SD) & $335.7 \pm 212.7$ & $340.7 \pm 215.8$ & $239.6 \pm 102.0$ & $P<0.001$ \\
\hline Mean SpO2 (SD) & $94.7 \pm 2.4$ & $94.7 \pm 2.4$ & $93.4 \pm 3.1$ & $P<0.001$ \\
\hline \multicolumn{5}{|l|}{ Novel Predictors } \\
\hline Mean D-Dimer (SD) & $405.0 \pm 3,699.8$ & $326.4 \pm 2,440.3$ & $1,906.2 \pm 12,614.9$ & $P<0.001$ \\
\hline Mean LDH (SD) & $229.1 \pm 214.9$ & $223.1 \pm 207.4$ & $343.5 \pm 305.5$ & $P<0.001$ \\
\hline Mean ALC (SD) & $1.4 \pm 2.0$ & $1.5 \pm 2.0$ & $1.3 \pm 1.6$ & $P=0.001$ \\
\hline Mean BUN (SD) & $19.4 \pm 15.1$ & $19.3 \pm 14.9$ & $21.2 \pm 18.4$ & $P<0.001$ \\
\hline Mean Troponin (SD) & $0.5 \pm 9.0$ & $0.6 \pm 9.2$ & $0.2 \pm 3.9$ & $P=0.002$ \\
\hline Mean CK (SD) & $173.7 \pm 1,612.7$ & $170.5 \pm 1,567.2$ & $235.4 \pm 2,316.0$ & $P=0.31$ \\
\hline Mean ALT (SD) & $21.1 \pm 20.6$ & $21.1 \pm 21.0$ & $20.9 \pm 10.4$ & $P=0.47$ \\
\hline Mean Lactate (SD) & $1.0 \pm 1.1$ & $1.0 \pm 1.1$ & $1.2 \pm 1.6$ & $P<0.001$ \\
\hline
\end{tabular}

The covariates included in the stacked model are calculated at a single point int time - the time of maximum SOFA score for each encounter. Presented are the summary statistics for all patients at that single point in time. FFP: fresh frozen plasm, PRBC: packed red blood cells, GCS: Glasgow comas score, $\mathrm{PF}: \mathrm{PaO} 2$ to $\mathrm{FiO} 2$ ratio, $\mathrm{LDH}$ : lactate dehydrogenase, ALC: absolute lymphocyte count, BUN: blood urea nitrogen, CK: creatinine kinase, ALT: alanine aminotransferase 
medRxiv preprint doi: https://doi.org/10.1101/2021.01.14.21249793; this version posted January 15, 2021. The copyright holder for this preprint (which was not certified by peer review) is the author/funder, who has granted medRxiv a license to display the preprint in perpetuity.

All rights reserved. No reuse allowed without permission.

Table 3: Model Area under the Receiver Operator Curve

\begin{tabular}{|c|c|c|c|}
\hline & $\begin{array}{c}\text { Retrospective Validation } \\
\text { Cohort } \\
(\mathrm{N}=16,418)\end{array}$ & $\begin{array}{c}\text { Prospective } \\
\text { Validation Cohort } \\
\qquad(\mathbf{N}=27,296)\end{array}$ & $\begin{array}{l}\text { COVID-19 Positive } \\
\text { Validation Cohort } \\
\qquad(\mathrm{N}=1,358)\end{array}$ \\
\hline SOFA & 0.90 & 0.90 & 0.85 \\
\hline qSOFA & 0.83 & 0.84 & 0.79 \\
\hline CURB-65 & 0.81 & 0.87 & 0.90 \\
\hline ARDS Mortality & 0.85 & 0.88 & 0.86 \\
\hline Charlson Comorbidity Index & 0.63 & 0.72 & 0.75 \\
\hline Novel Variables & 0.83 & 0.88 & 0.91 \\
\hline Stacked Model & 0.93 & 0.94 & 0.90 \\
\hline
\end{tabular}

The AUROC for each of the component models and the final stacked model. Models were trained and validated on the initial retrospective cohort. The models were then validated on the prospective cohort and on the subset of patients with COVID-19. The AUROC for the retrospective cohort is based on a $20 \%$ holdout of the encounters for testing and evaluation. The prospective validation cohort reflects expected performance when running in a live EHR for both COVID-19 positive and negative patients. 
medRxiv preprint doi: https://doi.org/10.1101/2021.01.14.21249793; this version posted January 15, 2021. The copyright holder for this preprint (which was not certified by peer review) is the author/funder, who has granted medRxiv a license to display the preprint in perpetuity.

All rights reserved. No reuse allowed without permission.

Figure 1: Study Data Flow: a) Data flow through the EHR and research team, b) Retrospective Cohort selection for model development, c) Prospective Cohort selection for model evaluation and validation

a.

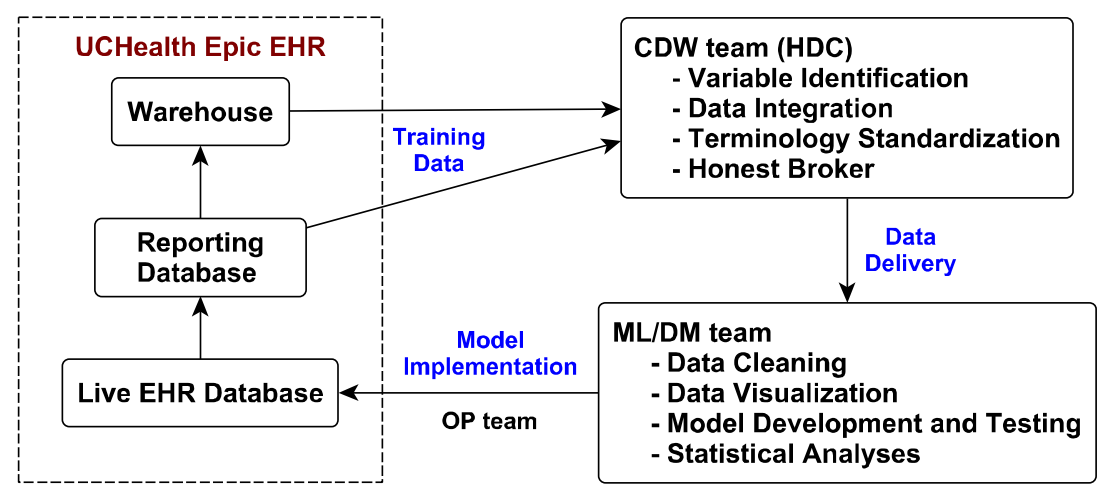

b.

92,460 ICU or Step-Down Admission Between August 2011 and March 4th, 2020

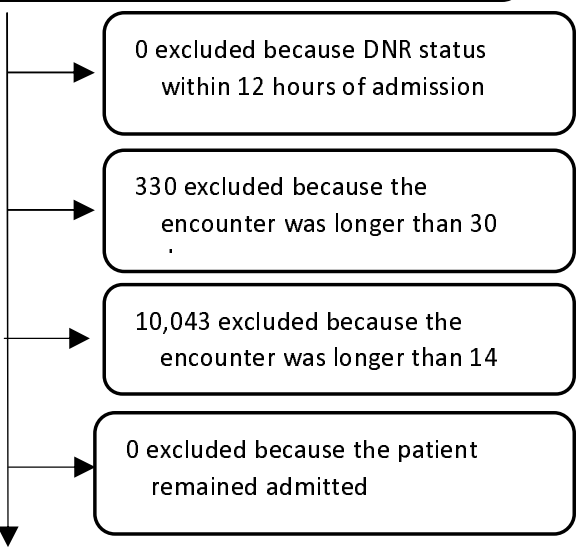

82,087 ICU or Step-Down Admissions Included for Model Development

c.

28,538 Hospital Admissions Between March

$15^{\text {th }}, 2020$ and July 4th, 2020

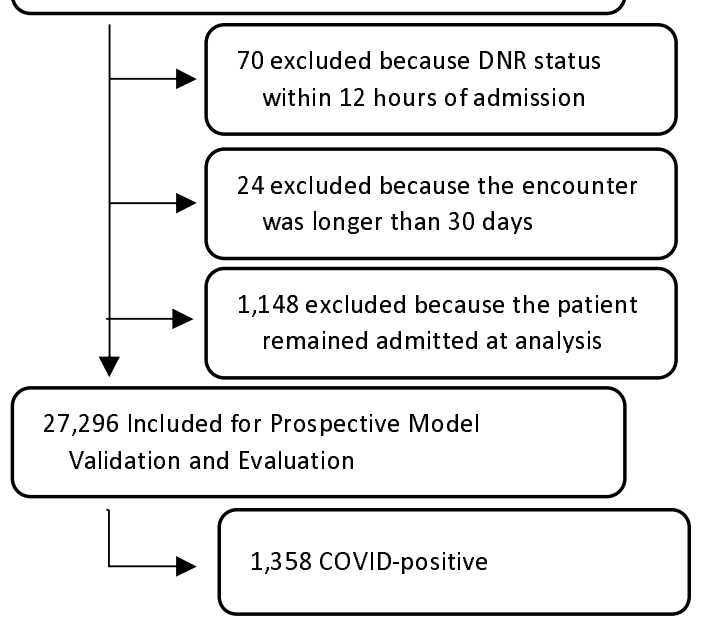


medRxiv preprint doi: https://doi.org/10.1101/2021.01.14.21249793; this version posted January 15, 2021. The copyright holder for this preprint (which was not certified by peer review) is the author/funder, who has granted medRxiv a license to display the preprint in perpetuity. All rights reserved. No reuse allowed without permission.

Figure 2: Stacked Model AUROC in the Retrospective and Prospective Cohorts: The retrospective cohort was used for training and validation (in a 40\%-40\%-20\% split). The prospective and COVID-19 positive cohorts were used to validate the retrospectively trained model.
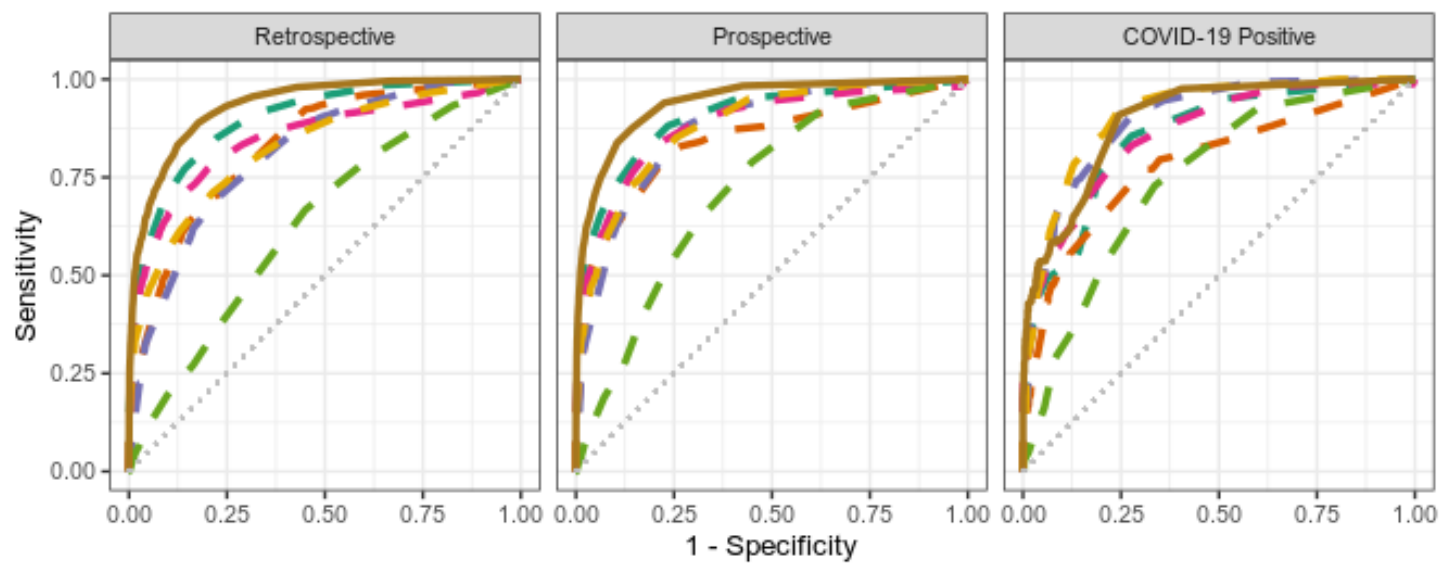

Model

$$
\begin{aligned}
& -\quad \text { SOFA }- \text { - ARDS Mortality } \\
& -\quad \text { qSOFA }-\quad-\text { Charlson Comorbidity Index } \\
& -\quad \text { CURB-65 }-\quad-\text { Novel Variable }
\end{aligned}
$$
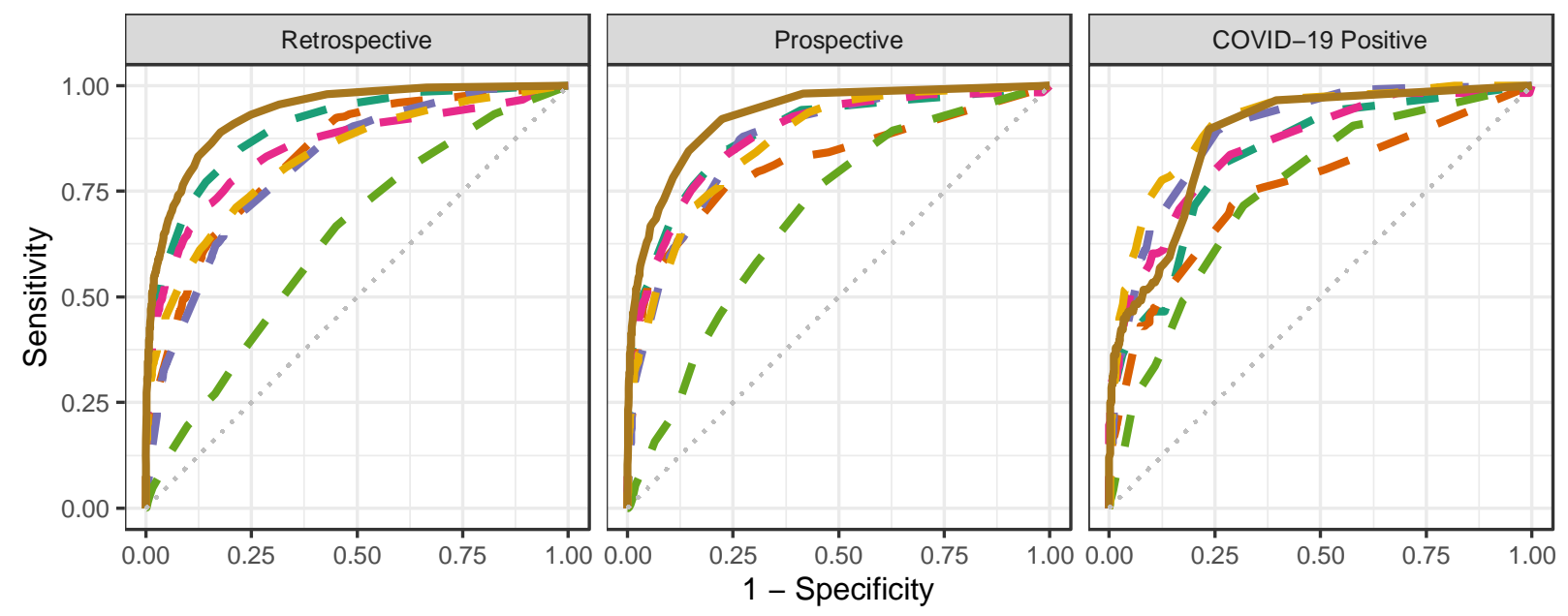

Model

$$
\begin{aligned}
& \square \text { SOFA }=\text { ARDS Mortality } \\
& \text { - qSOFA }=\quad \text { Charlson Comorbidity Index } \\
& - \text { CURB-65 }=\quad \text { Novel Variable }
\end{aligned}
$$

